\title{
Collaborative Learning: Building Ecological Awareness Through Social Studies
}

\author{
Mutiani ${ }^{1 *}$ Hendry Alfiani Arisandi ${ }^{1}$, M. Faisal ${ }^{1}$ \\ ${ }^{1}$ Department of Social Studies Education, Faculty of Teacher Training and Education, Lambung Mangkurat University, \\ Banjarmasin 70123, Indonesia \\ *Corresponding author. Email: mutiani@ulm.ac.id
}

\begin{abstract}
Environmental problems are issues that have not been exhaustively discussed in the global eyewear. Every environmental problems occurring human position as the main axis of the environmental damage that occurred. In the lowest level to educate absolute understanding of environmental awareness is given by teachers in each subject. The process to address the educational process is the implementation of collaborative learning. This article aims to describedescribes how collaborative learning can build environmental awareness and relation to social studies. Study literature used to describe the results of discussions in narrative form. In the context of building ecological awareness, collaborative learning affects the knowledge of students by touching the three main topics in environmental awareness, namely: 1) knowledge (the what, where, when, and why), 2) the attitude (the want to), and 3) skills (the how-to). It is aligned with the Social Studies material related to building environmental awareness in class VII Chapter I in particular the theme of People, Places and Environment.

Keywords; environmental awareness, collaborative learning, and social studies.
\end{abstract}

\section{INTRODUCTION}

Environmental problems are always a concern for all parties (global scale, national, or local). As for problems that arise starting from the needs of housing, food, fuel, until the waste piling up. The entirety of the problem causing environmental degradation [1]. As for the subject of damage to the environment itself is a human. In order to maintain the environmental, earth resource use can be made by building environmental awareness for the community [2],[3].

Awareness importance preserving the environment penting possessed by each individual. It is because we can not count on one hand to keep the environment sustainable, since conservation efforts will be more targeted and effective, if all stakeholders participate in these efforts [4]. The environmental movement grew not as a hobby, trend, interest or necessity, but because of the growing awareness of the environmental crisis of the environmental movement is movement in the world with over two million active institutions in the environment [5],[6].

Generally, there are three forms of movementliving environment, that is advocacy, action real and education, In practice the lowest level of education is the responsibility of each subject without exception Social Studies. Integrated Social Studies presented from several subjects: History, Geography, Economics, Sociology, Anthropology, to the Citizenship Education [7]. According to Gross, Messick, et al. (1978) "Social Studies are central in the proper general education of our young people, focusing as it does on Humankind, on our institutions, and our relationshsocial studies with nature and one another" [8]. Social Studies material are summarized in order to provide awareness to students as responsible citizens not only human beings, institutions (the state), but the natural surroundings [9], [10].

The challenge to make learners as responsible citizens demanding social studies teachers to have the skills in concocting an effective learning. The steps can be carried out by teachers is to promote collaborative learning. Collaborative learning is defined as a philosophy of learning that facilitate learner collaboration, fostering mutual, learn to change together, and move forward together [11], [12]. Therefore, this article aims to describe how collaborative learning can build environmental awareness and relation to social studies learning. This is due to the formation of active knowledge through collaborative learning can be implemented by Social Studies so that create dynamic learning environment, mutual cooperation, as well as conducive.

\section{RESEARCH METHODS}

The research used the document, literature, and journals to explain the concept of collaborative learning and ecological awareness through social studies. Literarture review uses the book, and journals. 


\section{DISCUSSION AND ANALYSIS}

\subsection{Collaborative Learning Concepts}

The concept of collaborative learning presented by Ted Panitz (1996) comes from a personal philosophy. This means not just learning techniques in the classroom [13]. Collaboration implies a lifestyle that makes collaboration as an interaction structure. The structure is designed such interactions in order to facilitate collective efforts to achieve common goals. In certain situations, when a number of people in a group, the collaboration is a great way to connect respect and value the capabilities and contribution of each group member [14].

Activities in collaborative learning there is a division of authority and acceptance of responsibility among the members of the group to carry out the action group. Main ideas underlying the collaborative learning is a consensus built up through cooperation among group members as opposed to a competition that promotes individual excellence [15]. The practitioners of this philosophy take advantage of collaborative learning in the classroom, in the committee meetings, in communities, in families and is widely as a way of life with and in touch with each other.

Etymologically states that the definition of collaboration that comes from the Latin root word with a meaning that emphasizes cooperation process while the word cooperation focusing on products such cooperation. Furthermore Myers showed some differences between the two concepts as follows:

Supporters of co-operative learning is growing niche to be more teacher-centered, for example when forming heterogeneous groups, structuring positive interdependence, and teaching co-operative skills. Collaborative learning advocates distrust structure and allow students more say if forming friendship and interest groups. Student talk is stressed as a means for working things out. Discovery and contextural approaches are used to teach interpersonal skills. Such differences can lead to disagreements .... I contend the dispute is not about research, but more about the morality of what should happen in the schools. Beliefs as to what should happen in the schools can be Viewed as a continuum of orientations toward curriculum from "transmission" to "transaction" to "transmission". At one end is the transmission position. As the name suggests, The aim of this orientation is to transmit knowledge to students in the form of facts, skills and values. The transformation position at the other end of the continuum stresses personal and social change in the which the person is said to be interrelated with the environment rather than having control over it. The aim of this orientation is self-actualization, personal or organizational change [16].

Collaborative learning make room for each other learners develop, learn and change together, and move forward together. Collaborative learning is more than just cooperative. If a cooperative learning techniques to achieve certain results faster, better, every person working less than if all working on their own, then cover the whole learning collaborative learning, participants teach each other. In fact, it is not possible, there are times when participants didk teach his teacher [12], [17].

Collaborative learning facilitate students to learn and work together, contribute ideas and be responsible for the achievement of learning outcomes as a group or individually [18]. In contrast to conventional learning, collaborative learning primary pressure "learn together". Collaborative learning as a pedagogy whose center lies in the assumption that humans are always creating shared meaning and process of the stretcher always enrich and broaden their horizons [13].

The core of collaborative learning is that learners learn in small groups. Among members of the group and learn from each other to achieve common goals. The group's success is the success of the individual and vice [19]. Collaborative work is a cooperative process which is done by both among individuals and among groups, mutual caring and respect fellow members to achieve a common goal.

Some of the benefits that can be gained through collaborative learning. The advantages of collaborative learning according to Hill \& Hill (1993) with respect to: 1) the achievement of higher learning; 2) a deeper understanding; 3) learning more fun; 4) develop leadership skills; 5) increasing positive attitude; 6) increasing selfesteem; 7) learn inclusively; 8) feeling of belonging; and 9) develop the skills of the future [20],[21].

Collaborative learning activities geared to instill habits (habits) to understand what is learned, the attitude of wanting to do something, and skills of how to do something. This is in line with the view which states that the attitude covers three main topics, namely: 1) knowledge (the what, where, when, and why), 2) the attitude (the want to), and 3) the skill (the how-to) [22]. Collaborative learning is a learning procedure in this case the learners learn together in groups and aimed to achieve objectives collectively [14],[15].

\subsection{Payload Environmental Education in Social Studies}

In the structure of scientific disciplines, it being understood that the Social Studies has the support of other disciplines. In addition to the Social Sciences as there is also a supporter of Social Studies Natural Sciences and humanities [23]. Natural science has three main sections covering disciplines, namely: Biology, Physics, and Chemistry. While composed of History and Literature. All fields of science and the humanities is rooted in a field called philosophy. Each individual philosophy that ultimately tipped on religious teachings. Thus, the structure of the Social Studies disciplines are described as follows: 
Figure 1 The structure of Social Studies Supporting Disciplines

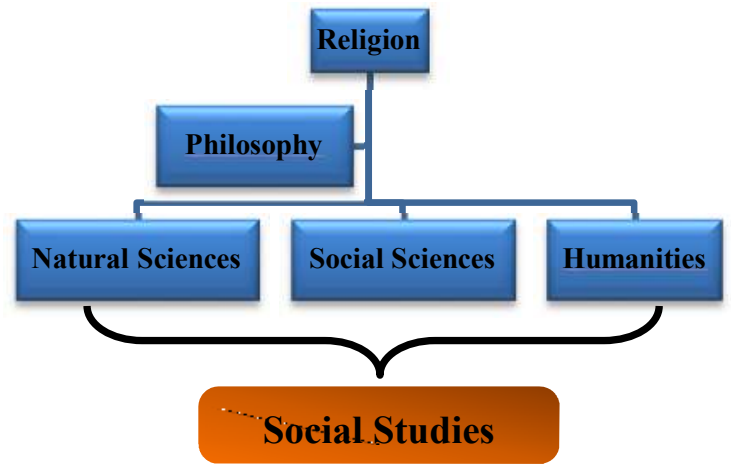

The above picture can be seen how the interrelationship of three different disciplines supporting Social Studies. Especially in the area of Natural Sciences that contribute Social Studies aims to prepare people to improve their lives respond to the challenges of increasingly advanced technologies and face social problems associated with nature in a responsible manner [10]. Therefore, Social Studies as a whole saw a human problem not only in behavior but also in the broader perspective of social life and nature [24]

In this perspective then expressed how important the Social Studies is prepared for global education. Global education encompasses a range of issues, such as; (1) The ecological system, (2) technology, (3) environmental issues, and (4) development issues [25]. Focus mainly environmental issues related to the exploitation of natural resources by humans, rapid population growth on earth, until consumerism resulting peak in the world ecological crisis. Problems and issues require solutions realized by the community. Everything may go beyond regional boundaries of an area and is expected to bring a shared concern [26]. Utilization of physical or non-physical environment in Social Studies is an important agenda to be realized as a major step for the ecological crisis response learners.

Therefore, ecology in the social environment specifically examines how their interactions within the environment. According to Barr, Barth, and Shermis (1978) Social Studies is a matter of ecological concern associated with the interaction therein, where the public aware of its role to establish, maintain, develop, and preserve it [25], [27] .Therefore, Social Studies is designed to develop aspects of knowledge, understanding, and analysis capabilities of the social conditions in entering the life of a dynamic society. This opinion is in line with the commitment of Research and Development, Ministry of National Education Curriculum Center (2010), which has identified 18 value which must be developed in order to bring the ideal character of Indonesian generation.

Integration of Social Studies concocted therein expected environmental education unlock the value of environmental awareness [23]. Social Studies can leveragediverse learning situations and different approaches to learning through education that exist in the environment so as to provide a strong emphasis on activities that are practical and provide direct experience (first - hand experience). Environmental awareness is useful for learners to research (examine) the major environmental issues from the perspective of the local, national, regional and international [10], [25]. So that learners can receive the environmental conditions in other geographical areas [7].

\subsection{Social Studies; Environmental Awareness in Curriculum 2013}

The education sector is spearheading to prepare human resources in order to have a comparative advantage in the life of the nation in the midst of the life of an increasingly globalized world. Educational activities will not stop as long as the country is still in need of qualified resources for the prosperity and the glory of the nation. In the educational process, potential learners should be developed as widely as possible so it can be beneficial for the development of the next generation to continue the development process. This is corroborated by the meaning of education according to Law No. 20 of 2003 on Openness of National Education which states that:

In realizing the goals of education in Indonesia as mandated by the Law Sidiknas the many obstacles both technical and non technical nature so that goal as if it is very difficult to achieve and ultimately education in Indonesia is generally carried out in a place without the meaning of progression. To build a new paradigm of education system in Indonesia in accordance with the demands of the times offers ten new paradigm in education, namely:

1. Education is a process of liberation

2. Education is a process to understanding

3. Education uphold children's rights

4. Education produces peace actions

5. Education is a process of empowerment of human potential

6. Education makes children with vision integrativ

7. Education became a vehicle to build character unity

8. Education produces a democratic man

9. Education produces people who care environment

10. School is not the only instrument of education

One paradigm offered Johan is education must produce people who care about the environment. Concern for the environment must be planted as early as possible in the educational process are realized in the learning activities [28]. From this paradigm then developed a model of environmental education. The boundaries of environmental education awareness to preserve the environment which is the source of life of the present generation and the generations to come [29]. Environmental education model proposed implies that education is not only emphasizes the understanding of the need for a balanced relationship between living beings and nature, but also to improve the attitudes and positive values to environmental issues [30]. Thus encouraging learners to do some form of direct action relating to the preservation of the environment around the learner. Required learners in the implementation of 
environmental education is learning patterns are simple, easy to understand and can be practiced in everyday life [31],[32].

Curriculum theme in 2013 is to produce Indonesian human being productive, creative, innovative, affective; through the strengthening of attitudes, skills and knowledge are integrated. 2013 character-based curriculum development aimed at improving the quality of education improvement process and results, leading to the formation of character and noble character of learners as a whole, integrated and balanced, in accordance with competency standards every academic year [33]. At the stage of implementation of the curriculum in 2013, integrating character education in any field of study contained in the curriculum, without exception Social Studies. Each learning materials relating to norms or values in each field of study needs to be developed, explicit, linked to the context of everyday life [34].

Social Studies in the curriculum in 2013 designated as a compulsory subject in Elementary School (SD) and Junior High School (SMP) is a subject that is expected to stimulate and develop the potential of learners in order to have the expected ability to improve the quality of the source human power [10]. One element that shows the high quality of human resources is the growing concern of the Indonesian people to the surrounding environment. In the 2013 curriculum learning materials Social Studies containing material directly related to the knowledge, management and environmental protection efforts [25].

The problem studied by students in touch with their natural state, the potential of nature and people's activities as an example in class VII Social Studies material. Learning materials are divided into four main sections, namely: 1) People, Place and the Environment; 2) Social Interaction and Social Institutions; 3) Human Activity in Meeting the Needs; 4) Community Life In The Praaksara Indonesia, Hindu-Buddhism, and Islam. The focus of the first chapter, the material is then divided into six sub-topics; a) understanding and interaction space, b) the location and spacious Indonesia, c) the potential of natural resources and maritime Indonesia, d) Indonesian population dynamics, e) natural conditions Indonesia, and f) changes due to interactions between rooms (Kemendikbud, 2013). If observed, each sub discussion discount on understanding regarding environmental linkages. In this case the Social Studies to develop materials based on the proper focus. Social Studies provide space for students to environmental awareness as a basic capital to appreciate and love the survival of the earth. To achieve the expected learning goals Social Studies can be done using a variety of approaches such as interdisciplinary, multidisciplinary and transdisciplinary in accordance with the characteristics of the Social Studies it self [10].

\section{CONCLUSION}

Collaborative learning is understood as learning that emphasizes the learning activities of students to work together. Cooperation among learners serve as a joint achievement to gain new knowledge or insight. In contrast to the meaning of cooperative learning that has a tendency of learning held by the teacher control. While the assumption brings collaborative learning together starting from a small group activity. In the context of ecological awareness building, collaborative learning is believed to influence the learners' knowledge. Collaborative learning is able to touch the three main topics in environmental awareness, namely: 1) knowledge (the what, where, when, and why), 2) the attitude (the want to), and 3) the skill (the how-to). In social studies learning diprakrasai build environmental awareness by teaching materials of class VII chapter I the theme People, Places, and Environment. Social Studies learning can be developed by using problemsdiverse social situations and especially environment problems. Thus, it is able to provide practical experience to respond to environmental problems through direct experience (first - hand experience).

\section{REFERENCES}

[1] D. Duckett, D. Feliciano, J. Martin-Ortega, and J. Munoz-Rojas, "Tackling wicked environmental problems: The discourse and its influence on praxis in Scotland," Landsc. Urban Plan., vol. 154, pp. 44-56, 2016.

[2] F. J. da Rocha Neves, "Innovation and employment: an agent-based approach for studying the effects of technological change on the labor market," 2017.

[3] N. Cardellicchio, C. Annicchiarico, A. Di Leo, S. Giandomenico, and L. Spada, "The Mar Piccolo of Taranto: an interesting marine ecosystem for the environmental problems studies," Environ. Sci. Pollut. Res., vol. 23, no. 13, pp. 1249512501, 2016.

[4] W. Piekarski, A. Dudziak, M. Stoma, D. Andrejko, and B. Ślaska-Grzywna, "Model Assumptions and Analysis of Ecological Awareness and Behaviour: an Empirical Study.," Polish J. Environ. Stud., vol. 25, no. 3, 2016.

[5] C. McIntyre and D. Medoro, "Spokesvultures for ecological awareness: An interview with Timothy Morton," ESC English Stud. Canada, vol. 42, no. 3, pp. 159-174, 2016.

[6] R. M. Mancha and C. Y. Yoder, "Cultural antecedents of green behavioral intent: An environmental theory of planned behavior," $J$. Environ. Psychol., vol. 43, pp. 145-154, 2015.

[7] M. Mutiani, "IPS DAN PENDIDIKAN LINGKUNGAN: URGENSI PENGEMBANGAN SIKAP KESADARAN LINGKUNGAN PESERTA DIDIK," SOSIODIDAKTIKA Soc. Sci. Educ. J., vol. 4, no. 1, pp. 45-53, 2017.

[8] M. Mutiani, "Pemanfaatan Puisi Sebagai Sumber Belajar Ips Untuk Menumbuhkan Kesadaran Lingkungan Peserta Didik Di SMP Negeri 6 Banjarmasin," J. Pendidik. Ilmu Sos., vol. 24, no. 
2, pp. 199-208, 2015.

[9] A. Bermudez, "Four tools for critical inquiry in history, social studies, and civic education," Rev. Estud. Soc., no. 52, pp. 102-118, 2015.

[10] S. Syaharuddin and M. Mutiani, "STRATEGI PEMBELAJARAN IPS: Konsep dan Aplikasi." Program Studi Pendidikan IPS Fakultas Keguruan dan Ilmu Pendidikan ..., 2020.

[11] S. Järvelä et al., "Enhancing socially shared regulation in collaborative learning groups: designing for CSCL regulation tools," Educ. Technol. Res. Dev., vol. 63, no. 1, pp. 125-142, 2015.

[12] C. Kaendler, M. Wiedmann, N. Rummel, and H. Spada, "Teacher competencies for the implementation of collaborative learning in the classroom: A framework and research review," Educ. Psychol. Rev., vol. 27, no. 3, pp. 505-536, 2015.

[13] M. Zainuri and D. Fawahid, "The Influence of Implementation Collaborative Learning Conduct to Virtual Laboratory to Increasing The Result of Study and Learning Activities on Science at Junior High School," Res. Rep., no. 2, 2016.

[14] P. N. Osipov and J. N. Ziyatdinova, "Collaborative learning: Pluses and problems," in 2015 International Conference on Interactive Collaborative Learning (ICL), 2015, pp. 361364.

[15] P. Ruengtam, "Cooperative/Collaborative Learning Technique in Theoretical Subjects of Interior Architecture Program," J. ASIAN Behav. Stud., vol. 3, no. 7, pp. 27-39, 2018.

[16] R. Brealey, Principles of corporate finance, concise. McGraw-Hill Higher Education, 2010.

[17] C. Schoor, S. Narciss, and H. Körndle, "Regulation during cooperative and collaborative learning: A theory-based review of terms and concepts," Educ. Psychol., vol. 50, no. 2, pp. 97119, 2015.

[18] M. Wang, B. Cheng, J. Chen, N. Mercer, and P. A. Kirschner, "The use of web-based collaborative concept mapping to support group learning and interaction in an online environment," Internet High. Educ., vol. 34, pp. 28-40, 2017.

[19] C. A. Kilgo, J. K. E. Sheets, and E. T. Pascarella, "The link between high-impact practices and student learning: Some longitudinal evidence," High. Educ., vol. 69, no. 4, pp. 509-525, 2015.

[20] Y. Sidani and S. Reese, "A journey of collaborative learning organization research," Learn. Organ., 2018.

[21] M. Iinuma, T. Matsuhashi, T. Nakamura, and H. Chiyokura, "Student awareness change in computer supported collaborative learning
(CSCL) environment," Int. J. Inf. Educ. Technol., vol. 6 , no. 6 , p. $448,2016$.

[22] K. L. Medsker, K. M. Holdsworth, and D. Brethower, "Models and strategies for training design," Perform. Improv., vol. 41, no. 4, pp. 4648, 2002.

[23] W. C. Parker, Social studies today: Research and practice. Routledge, 2015.

[24] Y. A. Ramdani and S. Sapriya, "Integration of local wisdom based on Naskah Amanat Galunggung in Civics learning," Masyarakat, Kebud. dan Polit., vol. 30, no. 4, pp. 418-427, 2017.

[25] D. Supardan, "Pendidikan Ilmu Pengetahuan Sosial: Perspektif Filosofi, Kurikulum dan Pembelajaran.” Bandung, 2014.

[26] P. J. Farris, Elementary and middle school social studies: An interdisciplinary, multicultural approach. Waveland Press, 2015.

[27] M. Muhaimin, "PENGEMBANGAN MODEL PROBLEM BASED LEARNING DALAM ECOPEDAGOGY UNTUK PENINGKATAN KOMPETENSI EKOLOGIS MATA PELAJARAN IPS." Universitas Pendidikan Indonesia, 2014.

[28] E. Manusia, S. A. Mufid, D. Fisik, C. Umum, and S. B. Mengajar, "Ekologi Manusia: dalam perspektif sektor kehidupan dan ajaran islam," 2010.

[29] C.-S. Lai, "A Study of Fifth Graders' Environmental Learning Outcomes in Taipei.," Int. J. Res. Educ. Sci., vol. 4, no. 1, pp. 252-262, 2018.

[30] S. Otto and P. Pensini, "Nature-based environmental education of children: Environmental knowledge and connectedness to nature, together, are related to ecological behaviour," Glob. Environ. Chang., vol. 47, pp. 88-94, 2017.

[31] M. E. Krasny, L. Kalbacker, R. C. Stedman, and A. Russ, "Measuring social capital among youth: applications in environmental education," Environ. Educ. Res., vol. 21, no. 1, pp. 1-23, 2015.

[32] M. C. Monroe, R. R. Plate, A. Oxarart, A. Bowers, and W. A. Chaves, "Identifying effective climate change education strategies: a systematic review of the research," Environ. Educ. Res., vol. 25, no. 6, pp. 791-812, 2019.

[33] M. Hosnan, Pendekatan saintifik dan kontekstual dalam pembelajaran abad 21: Kunci sukses implementasi kurikulum 2013. Ghalia Indonesia, 2014.

[34] E. Mulyasa, "Kurikulum tingkat satuan pendidikan: Sebuah panduan praktis," Bandung PT Remaja Rosdakarya, 2007. 